\title{
The Agency of Children in Nordic Medieval Hagiography
}

\begin{abstract}
Drawing upon medieval Nordic hagiographic sources, this article seeks to investigate traces of some of the more elusive medieval selves, those of medieval children. The question asked is what insights medieval Nordic saints' lives and miracle collections can offer into medieval children's agency and conceptions of self. We have to consider that these narratives are shaped by their authors, based on their recollected childhoods and encounters with children. Still, the analysis of the Nordic hagiographic corpus provides access to conceptions held about children by members of medieval Nordic societies; to the observed actions of medieval children and traces of their lived experiences; as well as to remembered childhood selves and echoes of children's voices and agency.
\end{abstract}

Keywords: childhood history, Nordic child miraculees, medieval children's agency, Nordic hagiography, childhood of Nordic saints

In the introduction to this anthology the editors ask: "What aspects of the medieval self are 'visible' and 'investigable' for us?" This chapter investigates traces of some of the more elusive medieval selves, that is, those of medieval children. They are certainly not the individuals that are easiest to find in medieval sources, nor are they the ones traditionally given the most attention from historians. Yet, they are far from invisible or unrepresented.

In the medieval Nordic hagiographic sources this chapter draws upon, it seems obvious and indisputable that medieval children were seen and heard, and that information about their lives and experiences was recorded. ${ }^{1}$ The story quoted below is a typical example. It represents one of 14 healing miracles from the A-legend of St Niels of Århus, De Vita et Miraculis B. Nicholai Arusiensis. The last one is dated to 1252, and the collection was most likely produced in

1 There has been a debate spanning several decades about the medieval conceptions of children and childhood and what kind of impact the high mortality rates had on these conceptions. This debate will not be engaged with here. For an overview of the discussion, see (Hanawalt 2002).

Rakel Igland Diesen, Norwegian University of Science and Technology

¿ Open Access. (C) 2020 Rakel Igland Diesen, published by De Gruyter. (cc) BY-NC-ND This work is licensed under a Creative Commons Attribution-NonCommercial-NoDerivatives 4.0 International License.

https://doi.org/10.1515/9783110655582-010 
connection with an effort by the Århus church to seek papal recognition of the saint (Olrik 1893, 293-4; Krötzl 1994, 70-3).

The miracle in question here will serve as point of departure for an investigation that aims at answering the following research question: What glimpses of medieval children's agency can Nordic hagiographies from the Middle Ages offer, and what can they say about conceptions of self? The story features a newly healed child going back and forth multiple times, offering oblations in the form of water from the saint's sacred spring:

A man had a son who from birth had been a cripple. He carried him to the grave of Saint Niels, and when the boy awoke after a deep sleep his tendons had relaxed and he was healed. When the father heard this, he did not believe it, until the boy, in everyone's presence, walked on his own, nine times, from the spring to the tomb and with his own hands that same number of times presented his offerings to Saint Niels.

[My translation, based on Gertz (1908) and Olrik (1893)]

There is something about this image of a boy performing repeated offerings of water to the shrine that is immediately recognizable as childlike. A similar expression of repetitive ritual behavior can be found in the vitae of Catherine of Siena. Her confessor, and the author of her vita, Raymond of Capua, tells the reader that she had confessed to him, on several occasions, that from the age of five she would kneel on each step and recite the Ave Maria when going up and down the stairs in her home (AASS, BHL 1702). Shulamith Shahar interprets this as typical childhood behavior, and not a topos (Shahar 1990,106). The actions of the boy who is said to be healed by St Niels can be interpreted in a similar way, that is, as an expression of the scribe's familiarity with age-typical conduct. On the other hand, to understand this kind of rendered child activity only or predominantly as an expression of what was deemed typical may be too a simplistic reading. It is pertinent to ask what the scribe's reason for including such descriptions might have been. He would perhaps be more interested in describing a child's devotional activity, rather than showcasing his own knowledge of childhood behavior? After all, one of the principal intended functions of the miracles was to read them aloud in order to inspire conversion, strengthen faith, and turn sinners to penance (Goodich 2007, 32; Ward 1987, 30-1).

The sources examined here are not uncritically taken to be accurate depictions of either actual events or children's actual lives. In religious writings, children were used as rhetorical tools to remind adults of their responsibilities (Rudolf 2018), and to evoke emotional responses in adults (Bailey 2017, 268-9). It is necessary to keep in mind that the textual representations of children found in miracle collections and vitae are based on or influenced by the memories and observations of a select group of adults, and that the personal accounts of childhood 
events that exist were given after the individuals themselves had become remembering adults. Nevertheless, I am inclined to agree with James Shultz (1995). In his own study of children in medieval German literature, he claims that if we refuse to speculate on what the lives of medieval children were like out of methodological squeamishness, we will be left knowing nothing about them at all (Schultz 1995, 263). This view is also supported by recent studies in childhood history and the methodological advances they have made when it comes to ways in which historical children can be approached (Aasgaard 2017). Of special interest in this context are recent attempts to shift the perspective from one that focuses on adults and their relationships with or conceptions of historical children and childhood to one that centers the agency of children themselves (Müller 2018, 7-13; Laes and Vuolanto 2017). Looking for historical children's agency and lived experience allows questions to be asked about what the children did, actively and maybe intentionally, and how they acted within their own societies.

In childhood history, it is often the careful accumulation of morsels of information that aggregate to supply valuable insights into both the conceptions held about children and childhood and the lived experiences of the children themselves. This is also the case when looking for traces of children's agency and expressions of self through echoes of their voices and actions in Nordic hagiography from the Middle Ages. Texts like the one quoted above as a point of departure yield themselves to accumulative close readings that produce information about the scribes' conceptions of childhood and child behavior. However, since the texts feature reflections of children's actions and voices, they may also give new insights into the agency and lived experiences of the children themselves.

Before focusing on my main question, it is necessary to present the sources and to underscore the conceptions of child and childhood that they present. Through close readings of first actions and then voices of children presented in these sources, I will then go on to discuss the glimpses of child agency that Nordic hagiographies from the Middle Ages can offer, and the access these glimpses give to different aspects of the lived experience and behavior of the elusive selves of medieval children.

\section{Children in Nordic Hagiographic Texts}

Miracles can be found in several types of texts, first and foremost in miracle collections, but also in other hagiographic genres like saints' lives, offices for saints, and sermons. In the Nordic context, they may in addition be represented 
in sagas and skaldic poetry. Moreover, miracle collections came in numerous forms. Sometimes they were collected in separate miracle books or appended to the lives of saints; oftentimes they were recorded in shrine books, of which there was often only one single exemplar; and sometimes they were collected in preparation for formal canonization processes (Bartlett 2013, 558-64, 576).

The manuscripts that gathered the recorded miracles of Nordic saints were predominantly produced in the twelfth to the fifteenth century, and they were generally written in Latin. Some collections, like the miracles of King Erik of Sweden, were translated into the vernacular in the Middle Ages. The Icelandic miracles are predominantly preserved only in the vernacular, although many of the hagiographic texts, such as the lives of Jón and Porlákr (Wolf 2008, 248-9; Cormack 2001, 596), were initially composed in Latin. Some of the Nordic miracle collections have several manuscript witnesses, with varying degrees of variance. The Passio et miracula beati Olaui is an example of a miracle collection with a more complex manuscript history (Jiroušková 2010, 223-32; 2014), while other collections, such as the miracles of Nils of Linköping, De miraculis $S$ Nikolai, are extant in a single manuscript witness (Schück 1895).

In these miracle collections taken together, there are around 250 miracles that feature child and adolescent miraculés. A more exact figure is difficult to give for several reasons, above all due to inconsistent definitions and conceptions of childhood. The terms puer or puella may, for instance, be used about adults, carrying reference to status rather than years of age (Bailey 2013, 202). Some miracle stories deal with adults who are healed from conditions suffered in childhood, and some of these stories also contain significant childhood narratives. Lastly, there are miracle stories where the miracule is not a child, but where children appear in roles as secondary characters. Concerning saints, some of the vitae of the roughly 50 saints associated with the Nordic countries (DuBois 2008, 15-9) have no account of the saint's childhood. More commonly, there are brief, and often rather formulaic, childhood narratives. The vitae of a few saints, such as Birgitta of Vadstena, have more developed childhood accounts.

The children portrayed in the lives of saints are future adults who not only represent themselves as children but also as a portent of what they will be when they grow up; they are, in short, aspiring saints, full of holy potential and future sainthoods. It has been argued that hagiographers, especially in the later Middle Ages, used narratives about the childhood and adolescence of saints deliberately to frame the saint's story and to set the scene for their future holiness. (Hill 2018, 161; McCreesh 2008, 121; Vauchez 1997, 508-10). It is, however, both interesting and important to note that such representation of future potential is not something found exclusively in the lives of saints. The same traits, such as the puer senex motif, have been pointed out in conjunction with saga literature, 
where children may also be portrayed to represent themselves as adults, and where childhood narratives may function as an introduction to their future adult selves (Ârmann Jakobsson 2017, 295-8).

The child miraculés from miracle collections can be understood as more ordinary children, encountered under extraordinary circumstances. Apart from stories where an individual that experienced a miracle as child is interviewed as an adult in connection with later canonization hearings, they do not figure as adults in the texts. They are presented as children, encountered in different environments, and portrayed as participating in a range of devotional and everyday activities. The miracles they undergo can be divided into two main groups, often employed as analytical categories in scholarship (Katajala-Peltomaa and Krötzl 2018 , 8). Miracles that transpire at the location of the shrine after a pilgrimage of prayer are often termed shrine miracles, and miracles that transpire at a distance from the shrine after the invocation of a saint, but with no direct contact with the saint's relics or tomb, are usually termed distance or invocation miracles (Krötzl 2018, 159-63).

Children who figure as secondary characters, in the lives of saints and in miracle stories, resemble the child miraculés in that they, too, are ordinary children. Examples are children who are the beneficiaries of miracles of provision, such as the children whose mother is able to feed them after St Niels of Århus saves her cow (De Vita et Miraculis B. Nicholai Arusiensis 1908, 400), or the starving children who are fed after St Porlákr aids their mother in finding a seal on the beach (Saga Porláks Biskups, hin elzta 1858, 122). Primarily, children in secondary roles are siblings, like the brothers who go with their mobility impaired sibling to the shrine of St Olav in Nidaros (Jiroušková 2014, 75), or playmates. In the latter case, they sometimes play a part in getting help for a child who has been in an accident, as is the case with the children who run to alert the mother of a fouryear-old boy who has drowned during play near a river (Sancti Willelmi Abbatis vita et miracula 1908-1912, 368-9). Playmates may also feature as part of miracle narratives that focus on the child's healed body and exemplify the restored body's functionality by describing the child's movement, for example, in play. One example is a group of boys playing together with the newly revived Gunmundus on the day of his drowning and revival (Gallén 1937, 35).

The inclusion of children as secondary characters is rather rare in Nordic Latin hagiography, but there appears to be a difference in frequency between the hagiography of Sweden, Denmark, and Norway, and the Icelandic Bishops' sagas and miracles. The latter seem to feature children somewhat more frequently. Several children are fostered by the bishops themselves, and the miracles contain ample circumstantial mention of children as a natural part of the environment, even when they are not the main beneficiary of the miracles. These children 
sometimes also act as helpers and messengers, like a girl who is sent to look for a missing woman (Jóns biskups saga, hin elzta 1858, 189), or the girl who conveys a message from St Porlákr about his inability to help everyone who asks for his aid (Jóns biskups saga, hin elzta 1858, 179-80).

Clearly, there are no texts in my selection written by children themselves, nor are there many instances where the children's own views or words seemingly are being cited or commented on. In addition, the texts are written not only by, but also primarily for, adults. As a consequence, even when the beneficiary of a miracle in a certain tale is a child, it is not necessarily the child's emotions or actions that are foregrounded, but rather those of the adults around it. Subsequently, when the author of the text presents the testimony of his informants, the children are rarely the ones given a voice by the scribe. It is far more common that an adult will speak, witness, or testify on behalf of the child. Moreover, the rare accounts of children who give witness in canonical hearings (Kuuliala 2013, 244) have also been recorded and filtered through the pens and minds of clerics and scribes. Consequently, what can be most readily observed in these sources is not the self-perception of children, but rather how a certain, limited group of adults viewed children and their actions.

The medieval hagiographic sources were written by celibate churchmen. When working with hagiographic texts, this biased selection of medieval views is a problem that must be acknowledged. However, the texts are not conveying the scribe's or author's views or experiences alone; they were the product of a discourse where the miraculées, the hagiographers, and the cultic community participated in producing narratives that can be read as a community's consensus memory (Craig 2009, 87-90). Furthermore, these miracle tales, through retelling, dissemination, and inspiration, also became prescriptive, prompting new pilgrims to undertake similar actions, as those of prior successful miracle seekers presumably shaping their conceptions of devotion and pilgrimage, and thereby also their ideas of children as devotional agents.

\section{Conceptions of Children}

One of the primary identifying qualities of children is that they are individuals who are not adults, they are other, and perhaps even less, than the quintessential medieval human, that is, the adult male. However, the distinction between child and adult found in hagiographic texts from the Nordic Middle Ages demonstrates that this is not a matter of a simple binary pair, child versus adult. The words used to describe the ages of a child, as well as when, and to whom, adult status is bestowed, is a more complex matter. 
Medieval life cycle definitions most commonly operate with two stages of childhood with a flexible boundary between them, infantia (infancy) and pueritia (childhood), usually ending at the age of fourteen or fifteen (Cochelin 2013, 8-13). When working with issues related to medieval children, it is common to cite either theories of ages of men (Youngs 2006, 18-23) or legal ideas about ages of discretion or majority as important concepts to comprehend how the medievals themselves understood the ages when the child transitioned into adulthood (Youngs 2006, 96-7). Looking to medieval laws from the Nordic region, it is evident that individuals less than fifteen winters old are considered minors in the Frostapinglög (Larson 2008, 272). But such formal ideas about age do not necessarily reflect the social practices regarding entry into adulthood, echoed in hagiographical sources where reality and the use of age-related terms sometimes seem to be less clear cut. This is especially true regarding the life stage known as adolescentia, a stage recognized by medieval society as an age between childhood and full adulthood, especially regarding males, ranging from early teens and sometimes as far as into the thirties, where the boy or young man had not taken on full maturity (Karras 2003, 13-5, 159). In the Nordic miracles, there is a certain fluidity in the use of age-related terms. There are 10year-olds called youths, such as one boy in the miracles of Catherine of Vadstena (AASS, BHL 1713), and 4-year-olds called infants (Vita sancti Brynolphi 1876, 144).

Furthermore, there are unmarried women, especially disabled ones, who are called girls and are given limited autonomy far into adulthood. In addition to this flexible use of age-related terms, there are also examples indicating that conceptions of children and childhood are defined by relations of power as well as chronological age. The men who wrote these tales still demonstrate an understanding of the limitations and capabilities of children of different ages. Sometimes this is explicitly stated, for instance in a miracle from St Nils of Linköping from the first quarter of the fifteenth century, where a future pilgrimage of thanksgiving from Odensvi to Linköping, about $80 \mathrm{~km}$, is promised on behalf of a half-year-old boy. The pilgrimage is stated to happen when the child is old enough to sit on top of a horse (Schück 1895, 378).

An example of the use of age-related terms with regards to adolescent girls can be seen when comparing two miracle accounts in the miracles of Nils of Linköping (Schück 1895, 355-66, 386). The first is a miracle story about Botildis who gives birth to conjoined twins, and the second is about Ramborghis who becomes ill with a serious illness. On Ramborghis' behalf, a vow is made by her father and two other men for her to travel to the shrine barefoot and without linens on, while for Botildis the vow is made by a woman who is helping her give birth. On behalf of both girls, the vows are of pilgrimage, and when they 
have recovered, the vows are carried out; Ramborghis traveling with her father and Botildis with her husband.

These two miracles are said to have happened two years apart, they are connected to the same saint, found in the same miracle collection, and readdressed in the canonization process of St Nils of Linköpig. The two girls are said to share the same age (15 years), but regardless of this, one is referred to as wife (uxor) and woman (mulier) while the other is referred to as daughter (filia) and girl (puella). Botildis, who is giving birth, is presented as an adult, and it is reasonable to assume that she herself would share that understanding. Ramborghis, who is ill and traveling with her father, is presented as a girl and daughter. In this context, age seems to be of secondary importance. Ramborghis' story illustrates that some Swedish young women over the age of majority, but still unmarried and living with their parents, did not have the full status of adults. Comparing the two examples thus underscores a point of more general importance: for many girls, the transition from adolescence to adulthood would have been related to marriage (Hanawalt 1995, 12-3).

\section{Children's Actions}

As is sometimes pointed out in studies more focused on material culture, children see the world from a different perspective than adults, lower parts of the environment, objects, and persons are within their reach, and they also direct their touch differently (Laurence 2016, 28). Furthermore, children engage with objects and spaces in their own ways, utilizing them for play and games, regardless of how adults would have intended them to be used (Crawford 2018, 21-9). The same considerations can be applied to children encountered in hagiographical literature; at the shrines, in the churches, and in their homes. They must have experienced the spaces mentioned in the texts in a uniquely childlike way, which means that their experience of and movement in the described environment was shaped by their size, vantage point, and individual interests. These perspectives may be helpful to bear in mind when envisioning the children in the environments described in miracle stories.

At the center of every miracle narrative dealing with the sick and their healing, the physical and material human body is found, which is what most miracle narratives revolve around. Children healed at the shrine are usually first encountered in a broken, sick, or disabled state, while children healed at a distant location may also be introduced as healthy, in transit or traveling, at work or in play, whereupon they are struck by sudden illness or become the unfortunate victim 
of an accident. Accordingly, the miracle narrative is often framed by two different descriptions of the miraculés bodily condition: first, the dysfunctional, disfigured, or diseased body, then the newly healed and now healthy body, sometimes described as beautiful or visually pleasing, and usually as active and functional. This narratological structure may be said to turn the genre of miracle stories into a treasure trove for descriptions of medieval children's bodies and activities, often showcasing a restored body engaged in sound activities such as playing, running, and eating. The active child is thus emphasized over the silent and invisible one. It represents an ideal, and the miracle stories reveal conceptions of what a healthy child would do and how it would act.

In our narrative point of departure - the story about the boy who repeatedly carries water from the holy spring to the shrine - descriptions of the child's physical condition and actions frame a discernible shift in agency. When the father brings the child to the shrine, the boy is primarily a prop while the father is the agent acting on his behalf. Immediately after the healing, however, the boy himself becomes the acting person at the center of attention. Many miracles feature a similar shift from adult, often parental, agency to child agency. This is especially noticeable in miracles concerning the smallest children, who, in the moment of healing, seem to become not only physically healthy, but also more autonomous agents. Initially, they are carried and presented by an adult; when healed, they gain initiative and act on their own, sometimes playing, sometimes performing devotional acts. In our miracle story, the child, who was brought to the shrine by his father and then fell asleep, becomes the focal agent and center of attention when he is transformed - not only from a mobility impaired to an able-bodied person, but also to an individual who, on his own accord, pursues devotional activities, thereby demonstrating what may be characterized as the somewhat playful religious agency of a medieval child.

Children and adolescents are portrayed in the miracles as performing a broad selection of activities either at the shrine of the saint, on pilgrimage, or away from the shrine, both inside and outside the home. Some of these children are portrayed as religious and devotional agents who may themselves be shown to invoke a saint and call upon her or him for help. One example is a 10-year-old boy called Holmstanus, who, according to the text, invokes St Birgitta to come to his aid when he is stuck on an ice float in the Swedish archipelago (Collijn 1924, 131-2). Another example is a young boy who calls on Bishop Porlákr when a fire threatens him and other children who are home alone at a farm in the Icelandic West Fjords (Saga Porláks Biskups, hin elzta 1858, 122).

According to Ronald Finucane, the vows of the marginal, the widows, the aged cleric and, most importantly in this instance, the little children (parvuli) were deemed especially potent (Finucane 1997, 13). In the Nordic miracles with 
child miraculés, the question of vows is treated in ways that portray children with varying degrees of responsibility and agency. An interesting example, which illustrates conceptions about ages of majority as well as the agency and responsibility of individuals of different ages, is found in the miracles of St Henricus. Here, a long-term vow of repeated pilgrimage to the saint's shrine in the cathedral in Turku (Åbo) is explicitly said to be handled by the parents until the child has reached the age of discretion. (Heikkilä 2009, 270-2) There are also examples of children who invoke a saint without any appearance of $d o$ $u t$ des. As seems to be the case with the previously mentioned boy who calls on Bishop Porlákr when a fire breaks out, the child invokes the saint on its own initiative, not promising anything in return. In these narratives, children who would, under most circumstances, be considered too young to enter into a legally binding contract or make a vow appear to be granted an exemption when they get the saint to intercede on their behalf.

\section{Children's Voices}

In hagiography, as in other medieval genres and sources, children's own voices are rarely, if ever, recorded. What can be found are the voices of children mediated, molded, and narrated by adults who, most likely, had limited contact with children. There are many instances of such referenced speech in the miracles recorded in collections and canonization hearings. However, while possible vestiges of children's voices might imply a certain level of closeness to the statements originally made by the witness (Fröjmark 2018), there is no way to ascertain that the instances of direct or reported speech found in the miracle stories are actual renderings of a child's utterances.

In a miracle found in a fourteenth-century collection associated with the shrine of St Erik at Uppsala, the Vita et Miracula Sancti Erici, there is an instance of what appears to be a testimony given directly from a former child miraculé: "Olavus, from the parish of Huddunge, said of himself that when he was a seven-year-old boy he lost his mind for a year and a half" (Nelson 1944, f $14 \mathrm{r}, \mathrm{v})$. The text presents the narrative as Olavus' retelling of his own history, and what is found here is, arguably, an instance of a medieval adult's remembered childhood self. When expressions of self-representations are found in these texts, this is most often the case: they are communicated by an adult who is said to recount an incident that happened in his or her childhood.

In the lives of visionary saints, there are several narratives based on the saint's reminiscences of childhood, and recorded by their confessors (Voaden 
and Volf 2000). In the Nordic sources, St Birgitta's childhood narrative is a prominent example. Her five childhood visions are retold in the first part of her vitae, which is written by two of her confessors, found among the acts of her canonization process (Harris 1990, 14-5), and said to have occurred between the age of seven and Birgitta's marriage at fourteen (Collijn 1924: 614-6). Her adult recollections resemble other adult testimony about childhood experience, both removed in time as the remembered childhood-self of an adult witness and shaped by convention and genre. As such, they carry the same potentials and limitations as other hagiographic sources.

Due to increased documentation demands brought about by the development of the formal canonization processes, the miracula genre changed in substantial ways during the medieval period. Miracles recorded in the context of canonizations are often characterized by being richer in detail than their earlier, locally recorded counterparts, as they tend to include more information about environmental, social, and circumstantial topics. The resulting texts have been held to represent a type of hagiographic material that is closer to the historical event than previous compilations of miracles (Katajala-Peltomaa 2009, 18-9).

The regulations and the clerical control of the canonization processes shaped the proceedings regarding what questions would be asked (Goodich 2007, 87-94), and who would be interviewed. Gender, wealth, reputation and, most importantly in our context, age of maturity were all selection criteria for witnesses (KatajalaPeltomaa 2018, 227). The interrogated witnesses to the reported miracles were often parents, neighbors, and other persons from the child's local community; sometimes the former child miraculé her- or himself was also included among the witnesses. When several witnesses testified to the circumstances and events of a certain miracle, there is sometimes a layering of narratives that produces a more detailed and vivid image of the circumstances discussed and provides more detail about the individual child's lived experience and self-understanding.

According to canon law, children under the age of fourteen were not considered able to take an oath. Consequently, children are rarely encountered as witnesses in canonization hearings (Kuuliala 2013, 244). In the twelfth century, when a large part of canon law was worked out, issues concerning children were also touched upon. The conclusion of the lawmakers was that religious belief only fully matured as the child entered puberty. As a consequence, mortal sin was seen as the domain of adults; a child could not commit the kind of mortal sin that would earn them damnation (Orme 2017, 321). One should also keep in mind that medieval theologians did not regard it necessary for children to give confession, get absolution, or pay penances; only after puberty were children expected to participate in these religious activities (Orme 2017, 320). These beliefs and practices 
underscore that children had a different legal and moral status than adults, which is also reflected in the general lack of child witnesses.

All the extant records of canonization hearings in the Nordic region are related to Swedish saints. In these canonization records, there are some young adults who testify to their own recollection of events that are said to have transpired only a few years before. These are former child miraculés, who, at the time of the canonization processes, had reached legal maturity, and who testified to the correctness of an article describing his or her miraculous healing. These are not children recounting their experiences from the vantage point of the child, but adult retrospectives on events from childhood and adolescence, drawing on memories of a past childhood self.

In 1417, the Swedish church, with the support of Rome, started canonization proceedings in the case of three saints, Ingrid of Skänninge, Brynolf of Skara, and Nils of Linköping. From the canonization processes of the two male saints the whole proceedings are extant, but in the case of Ingrid of Skänninge only a few fragments exist today. In the miracles of Brynolf of Skara, no former child miraculés are recorded as witnesses. In the canonization hearings of Nils of Linköping, four former child or adolescent miraculés give testimonies, in addition to the aforementioned Botildis, here 22 years old. The 22-year-old Thomas, 21year-old Ingefridis, and 26-year-old Ramborghis all testify to the truth of the articles describing the miraculous healings said to have transpired (Lundén 1963, 314, 332, 342-4). In all three miracle texts, it seems clear that they are not afforded adult status at the time of their miracles. Thirteen-year-old Ericus is the youngest individual to testify in this canonization process: this adolescent testifies to the truth of the article concerning his healing at the age of nine (Lundén 1963, 320).

An interesting instance of a former child miraculé testifying during a canonization process is found in the sparse extant fragments from the canonization process of Ingrid of Skänninge, conducted in the summer of 1417. The article narrating the event of the boy Gunmundus who drowned in a well and was revived is lost, but three witness testimonies to the events surrounding his drowning and subsequent revival still exist. Among them there is one rare example of a young adult, the then 20-year-old Gunmundus, giving testimony to the events that are said to have happened 16 years earlier. Gunmundus not only attests to the truth of the article according to his own memory, he also testifies that the article describes the events as "fore uera quia sic in se ipso sensit et ab aliis audiuit ueraciter contigisse," that is, as he himself experienced them and as he has been told that they really came to pass (Gallén 1937, 34-5). This retelling of the event by others is clearly stated as a source of knowledge to the young man's dramatic childhood experience. Consequently, Gunmundus, on the one hand, claims to base his approval of the article on his own recollection, and on the 
other, on the story that he, most likely, has been told multiple times throughout his childhood. This story is also stated to be publicly known in the entire district.

It is plausible that actions described in the miracles were influenced and shaped by real children. The voices of these children are, however, harder to access. Yet, there are instances where the reported voices of named individuals bring forth remembered childhood selves, and these contribute to a more vivid picture of what may be termed their rhetorical agency.

\section{Concluding Remarks}

When new social groups are included, and their history explored, new questions arise, and we are made aware of new perspectives, mechanisms, and ideas. Children's history expands on what is considered the purview of history and historians, and so, traditional assumptions about who counts in history become destabilized (Saxton 2010).

Returning to our narrative point of departure, it might be said that the author of the text presents the reader with a child who acts intentionally. Bringing donations of water from the sacred spring to the shrine, this boy, on the one hand, participates in a well-established religious practice, probably imitating devotional actions he has observed. On the other hand, his repetitive donations add an aspect of childlike invention. What is seen in this story is arguably the reflection of a medieval child's religious agency, here represented by a young boy portrayed as a devotional, religious agent, acting in ways that both conform and break with expected religious activity and devotional practice. I am not disregarding an element of play in this activity, but I am also inclined to interpret it as an expression of religious learning and cognition. The boy's actions can be read as an instance of socially situated learning, in this case involving cognitive processes such as recognizing the intentions of other people, imitation, and inventive incorporation of observed actions into a ritual which is childish in ways demonstrating that a well-established adult practice is not yet fully internalized and mastered.

The children found in the Nordic miracles are in several ways presented as active individuals with agency and autonomy. They initiate and go on pilgrimage; they invoke saints, pray, and give vows on their own behalf; they travel alone or in groups, over long distances as well as locally; they get lost, give aid to each other, and play together or on their own. In this sense, the miracles studied give access to the lived experience and behavior of medieval children in the Nordic region. 
Admittedly, the perspectives encountered in medieval hagiographic texts are primarily, if not exclusively, those of adults. However, they are nonetheless influenced by interaction with medieval children (Zottl 2006, 3-4). Medieval adults would draw on memories of their own childhoods when writing their narratives, as former child miraculés also did when testifying to their own childhood experiences. Shaped by remembered childhoods and encounters with children living in specific localities in specific times, miracle stories provide access not merely to the scribes' conceptions of children and childhood, or the outward and observed actions of children themselves, but also to traces of medieval children's lived experiences and to echoes of their voices. Taken together, they thus give new insights into conceptions held about children by members of medieval Nordic societies, as well as the agency and selves of medieval children. Reaccentuating the editors' introductory question, it is therefore my claim that hagiographic sources such as the ones studied contribute to making aspects of medieval children both "visible" and "investigable."

\section{References}

\section{Primary Sources}

De Vita et Miraculis B. Nicholai Arusiensis. 1908. In Vitae Sanctorum Danorum. Ed. M. Cl. Gertz. Copenhagen. 398-406.

Jóns biskups saga, hin elzta. 1858. In Biskupa sögur 1: Fyrsta bindi. Ed. Íslenzka bókmentafélag. Copenhagen. 149-202.

Saga Porláks Biskups, hin elzta. 1858. In Biskupa sögur 1: Fyrsta bindi. Ed. Íslenzka bókmentafélag. Copenhagen. 87-124.

Sancti Willelmi Abbatis vita et miracula. 1908-1912. In Vitae Sanctorum Danorum. Ed. M. Cl Gertz. Copenhagen. 300-69.

AASS = Vita cum miraculis b. Katherine, Miracula annis 1469-1474 iuridice collecta. 2006.

In Acta Sanctorum, BHL 1730 “Acta Sanctorum Database: The Full Text Database.” 2006. [S.I.]. http://acta.chadwyck.com.

Vita sancti Brynolphi episcopi Scarensis cum processu eius canonizacionis. 1876. In Scriptores rerum Svecicarum medii aevi 3:2. Ed. Erik Gustav Geijer, Erik Michael Fant, and Johan H Schröder. Uppsala. 138-85.

\section{Secondary Sources}

Aasgaard, Reidar. 2017. "How Close Can We Get to Ancient Childhood? Methodolgical Achievements and New Advances." In Children and Everyday Life in the Roman and Late Antique World. Ed. Christian Laes and Ville Vuolanto. London. 318-31. 
Ármann Jakobsson. 2017. "Viking Childhood.” In Childhood in History: Perceptions of Children in the Ancient and Medieval Worlds. Ed. Reidar Aasgaard and Cornelia Horn. London and New York. 290-304.

Bailey, Anne E. 2013. "Wives, Mothers and Widows on Pilgrimage: Categories of 'Woman' Recorded at English Healing Shrines in the High Middle Ages." Journal of Medieval History 39.2: 197-219.

Bailey, Anne E. 2017. “Miracle Children: Medieval Hagiography and Childhood Imperfection.” The Journal of Interdisciplinary History 47.3: 267-85.

Bartlett, Robert. 2013. Why Can the Dead Do Such Great Things?: Saints and Worshippers from the Martyrs to the Reformation. Princeton, NJ.

Cochelin, Isabelle. 2013. "Introduction: Pre-Thirteen-Century Definitions of the Life Cycle." In Medieval Life Cycles: Continuity and Change. Ed. I. Cochelin and K.E. Smyth. International Medieval Research, 18. Turnhout. 1-54.

Collijn, Isak. 1924. Acta et processus canonizacionis beate Birgitte. Samlingar utgivna av Svenska fornskriftsällskapet. Uppsala.

Cormack, Margaret. 2001. "Saga of Bishop Jón of Hólar.” In Medieval Hagiography: An Anthology. Ed. Thomas Head. New York. 595-626.

Craig, Leigh Ann. 2009. Wandering Women and Holy Matrons: Women as Pilgrims in the Later Middle Ages. Studies in Medieval and Reformation Traditions, 138. Leiden.

Crawford, Sally. 2018. "Childhood and Adolescence: Interdisciplinary Approaches to the Archaeological and Documnetary Evidence." In Childhood and Adolescence in Anglo-Saxon Literary Culture. Ed. Winfried Rudolf and Susan Irvine. Toronto Anglo-Saxon Series, 28. Toronto. 15-31.

DuBois, Thomas A. 2008. Sanctity in the North: Saints, Lives, and Cults in Medieval Scandinavia. Toronto Old Norse-Icelandic Studies. Toronto.

Finucane, Ronald C. 1997. The Rescue of the Innocents: Endangered Children in Medieval Miracles. Basingstoke.

Fröjmark, Anders. 2018. "Telling the Miracle: The Meeting between Pilgrim and Scribe as Reflected in Swedish Miracle Collections." In Miracles in Medieval Canonization Processes: Structures, Functions, and Methodologies. Ed. Christian Krötzl and Sari Katajala-Peltomaa. Turnhout. 131-56.

Gallén, Jarl. 1937. "Les causes de Sainte Ingrid et des Saints Suédois au temps de la Réforme." Archivum fratrum praedicatorum 7. 5-40.

Gertz, Martinus Clarentius. 1908. Vitae Sanctorum Danorum. Copenhagen.

Goodich, Michael. 2007. Miracles and Wonders: The Development of the Concept of Miracle, 1150-1350. Church, Faith, and Culture in the Medieval West. Aldershot.

Hanawalt, Barbara A. 1995. Growing Up in Medieval London: The Experience of Childhood in History. Oxford Paperbacks. New York and Oxford.

Hanawalt, Barbara A. 2002. "Medievalists and the Study of Childhood." Speculum 77.2: 440-60.

Harris, Marguerite Tjader. 1990. “Introduction.” In Birgitta of Sweden, Life and Selected Revelations. Ed. Marguerite Tjader Harris. The Classics of Western Spirituality, 1. New York. 13-52.

Heikkilä, Tuomas. 2009. Sankt Henrikslegenden. Skrifter utgivna av Svenska litteratursällskapet i Finland, 720. Helsingfors. 
Hill, Joyce. 2018. "Childhood in the Lives of Anglo-Saxon Saints." In Childhood and Adolescence in Anglo-Saxon Literary Culture. Ed. Winfried Rudolf and Susan Irvine. Toronto Anglo-Saxon Series, 28. Toronto. 139-61.

Jiroušková, Lenka. 2010. "Textual Evidence for the Transmission of the Passio Olavi Prior to 1200 and Its Later Literary Transformations." In Saints and Their Lives on the Periphery: Veneration of Saints in Scandinavia and Eastern Europe (c. 1000-1200). Ed. Ildar

H. Garipzanov and Haki Antonsson. Cursor mundi, 9. Turnhout. 219-39.

Jiroušková, Lenka. 2014. Der heilige Wikingerkönig Olav Haraldsson und sein hagiographisches Dossier: Text und Kontext der Passio Olavi (mit kritischer

Edition): vol. 2: Edition und Bildmaterial. Mittelateinische Studien und Texte, 46. Leiden.

Karras, Ruth Mazo. 2003. From Boys to Men: Formations of Masculinity in Late Medieval Europe. The Middle Ages Series. Philadelphia.

Katajala-Peltomaa, Sari. 2009. Gender, Miracles, and Daily Life: The Evidence of Fourteenthcentury Canonization Processes. Studies in the History of Daily Life, 1. Tunhout.

Katajala-Peltomaa, Sari. 2018. "Narrative Strategies in the Depositions: Gender, Family, and Devotion.” In Miracles in Medieval Canonization Processes: Structures, Functions, and Methodologies. Ed. Christian Krötzl and Sari Katajala-Peltomaa. International Medieval Research, 23. Turnhout. 227-56.

Katajala-Peltomaa, Sari and Christian Krötzl. 2018. “Approaching Twelfth-to Fifteenth-Century Miracles: Miracle Registers, Collections, and Canonization Processes as Source Material.” In Miracles in Medieval Canonization Processes: Structures, Functions, and Methodologies. Ed. Christian Krötzl and Sari Katajala-Peltomaa. International Medieval Research, 23. Turnhout. 1-39.

Krötzl, Christian and Sari Katajala-Peltomaa, eds. 2018. Miracles in Medieval Canonization Processes: Structures, Functions, and Methodologies. International Medieval Research, 23. Turnhout.

Krötzl, Christian. 1994. Pilger, Mirakel und Alltag: Formen des Verhaltens im skandinavischen Mittelalter (12.-15. Jahrhundert). Studia historica, 46. Helsinki.

Krötzl, Christian. 2018. "Miracula post mortem: On Function, Content, and Typological Changes." In Miracles in Medieval Canonization Processes: Structures, Functions, and Methodologies. Ed. Christian Krötzl and Sari Katajala-Peltomaa. International Medieval Research, 23. Turnhout. 157-75.

Kuuliala, Jenni. 2013. Disability and Social Integration in the Middle Ages: Constructions of Childhood Impairments in Thirteenth- and Fourteenth-century Canonisation Processes. Studies in the History of Daily Life, 4. Tunhout.

Laes, Christian and Ville Vuolanto, eds. 2017. Children and Everyday Life in the Roman and Late Antique World. London.

Larson, Laurence Marcellus. 2008. The Earliest Norwegian Laws: Being the Gulathing Law and the Frostathing Law. Clark, NJ.

Laurence, Ray. 2016. "Children and the Urban Environment: Agency in Pompeii." In Children and Everyday Life in the Roman and Late Antique World. Ed. Christian Laes and Ville Vuolanto. London. 27-42.

Lundén, Tryggve. 1963. Sankt Nikolaus av Linkøping kanonisationsprocess = Processus canonizacionis beati Nicolai Lincopensis. Processus canonizacionis beati Nicolai Lincopensis. Stockholm. 
McCreesh, Bernadine. 2008. "The Birth, Childhood and Adolescence of the Early Icelandic Bishops." In Youth and Age in the Medieval North. Ed. Shannon Lewis-Simpson, Northern World, 42. Leiden. 87-102.

Müller, Miriam. 2018. Childhood, Orphans and Underage Heirs in Medieval Rural England: Growing Up in the Village. Palgrave Studies in the History of Childhood. Cham.

Nelson, Axel. 1944. Vita et miracula Sancti Erici regis Sueciae, Latine et Suecice. Codex Vat. Reg. Lat 525. Suecice et Britannice Praefatus. Corpus codicum Suecicorum medii aevi, 3. Hafniae.

Olrik, Hans. 1893. Danske helgeners levned. Skrifter (Selskabet til historiske kildeskrifters oversættelse). Copenhagen.

Orme, Nicholas. 2017. "Perceptions of Children in Medieval England." In Childhood in History: Perceptions of Children in the Ancient and Medieval Worlds. Ed. Reidar Aasgaard and Cornelia Horn. New York. 318-33.

Rudolf, Winfried. 2018. "Anglo-Saxon Preaching on Children.” In Childhood and Adolescence in Anglo-Saxon Literary Culture. Ed. Winfried Rudolf and Susan Irvine. Toronto AngloSaxon Series; 28. 48-70.

Saxton, Martha. 2010. "Introduction." The Journal of the History of Childhood and Youth 3.3: 313-5.

Schück, Henrik. 1895. "De miraculis S. Nicolai, in Två svenska biografier från medeltiden.” Antiqvarisk tidskrift för Sverige 5: 333-400.

Schultz, Jr. James A. 1995. The Knowledge of Childhood in the German Middle Ages, 1100-1350. Middle Ages Series. Philadelphia.

Shahar, Shulamith. 1990. Childhood in the Middle Ages. London.

Vauchez, André. 1997. Sainthood in the Later Middle Ages. Trans. Jean Birrel. Cambridge.

Voaden, Rosalynn and Stephanie Volf. 2000. "Visions of My Youth: Representations of the Childhood of Medieval Visionaries." Gender \& History 12.3: 665-84.

Ward, Benedicta. 1987. Miracles and the Medieval Mind: Theory, Record and Event, 1000-1215. Rev. ed. Philadelphia.

Wolf, Kirsten. 2008. "Pride and Politics in Late-Twelfth-Century Iceland: The Sanctity of Bishop Porlákr Pórhallsson." In Sanctity in the North: Saints, Lives, and Cults in Medieval Scandinavia. Ed. Thomas A. DuBois. Toronto Old Norse-Icelandic Series, 3. Toronto. 241-70.

Youngs, Deborah. 2006. The Life Cycle in Western Europe, c.1300-c.1500. Manchester.

Zottl, Christian M. 2006. "Quae voces audio?" Concilium medii aevi 9: 1-21. 
